\title{
Mesenchymal Stem Cells: The First Approved Stem Cell Drug in Japan
}

\author{
Yuho Najima, Kazuteru Ohashi \\ Tokyo Metropolitan Cancer and Infectious diseases Center, Komagome Hospital, Hematology division
}

Acute graft-versus-host disease (aGVHD) is one of the most frequent complications after allogeneic hematopoietic stem cell transplantation (HSCT). First-line therapy for aGVHD usually consists of corticosteroids, but almost half of patients fail to respond, and more than $60 \%$ eventually die. Although several treatment options have been developed as second-line therapy, currently, no established strategy for steroid-refractory (SR) aGVHD is available. Mesenchymal stem cells (MSCs) have unique immunoregulatory properties that make them attractive for use in salvage therapy for SR-aGVHD. Following the striking clinical course reported by Le Blanc's group, many clinical trials have shown favorable results of MSC infusions for SR-aGVHD. In Japan, two clinical trials were performed. Following the favorable results of clinical studies, MSCs have become the first approved stem cell drug for SR-aGVHD. This therapy is called TEMCELL. In this review, we briefly summarize the current status and problems with MSCs in Japan. Now that this cell drug is available to all eligible patients, a post-marketing study is needed to answer crucial clinical questions. (Journal of Hematopoietic Cell Transplantation 6 (3): 125-132, 2017.)

\section{Introduction}

Various advances in the care of patients undergoing HSCT have improved the outcomes following transplantation. ${ }^{1} \mathrm{Nev}$ ertheless, aGVHD remains the most frequent complication after allogeneic HSCT and is often fatal. First-line therapy for aGVHD usually consists of corticosteroids, such as $2 \mathrm{mg} / \mathrm{kg}$ / day methylprednisolone for 7-14 days, but 40-50\% of patients fail to respond. ${ }^{2}$ The prognosis of steroid-refractory aGVHD (SR-aGVHD) is quite dismal, with mortality of over $60 \%$. Thus, effective second-line treatment for SR-aGVHD has been long awaited. Although promising results for several treatment options including anti-thymocyte globulin (ATG) ${ }^{3}$ mycophenolate mofetil (MMF) ${ }^{4}$ methotrexate (MTX), ${ }^{5}$ and tumor necrosis factor $\alpha$ antagonist ${ }^{6}$ were reported, no consensus has been established regarding the selection of salvage therapy for SR-aGVHD.

Mesenchymal stem cells (MSCs) have unique immunoregulatory properties that make them an attractive option for salvage therapy. Following the promising results of phase I /
II $^{7}$ and phase II / III ${ }^{8}$ studies, MSCs have become the first approved stem cell drug for SR-aGVHD in Japan. An excellent, comprehensive review paper was published describing the sequence of events in achieving insurance approval of MSCs for SR-aGVHD treatment in Japan. ${ }^{9}$ In addition, a sophisticated review paper was published previously regarding the clinical application of MSCs. ${ }^{10}$ In this article, we briefly summarize the updated evidence and status of MSCs for SR-aGVHD.

\section{Characteristics of MSCs}

The definition of MSCs has three minimum requirements. ${ }^{11,12}$ 1) MSCs are spindle-shaped adherent cells, 2) MSCs are positive for the surface markers CD105, CD73, and CD90 and negative for the leukocyte markers CD34, CD45, CD11b, CD19, and HLA-DR, and 3) MSCs have tri-lineage multipotency. They can differentiate into osteocytes, adipocytes, and chondrocytes. Due to this property, MSCs are expected to be applicable in regenerative medicine. ${ }^{12}$

Submitted November 2, 2016; Accepted January 16, 2017; Published online, July 18, 2017. (Handling Editor: Naoyuki Uchida, Toranomon Hospital)

Key words: Mesenchymal stem cell, acute graft-versus-host-disease, allogeneic stem cell transplantation

Correspondence: Yuho Najima, Hematology division, Tokyo Metropolitan Cancer and Infectious diseases Center, Komagome Hospital, 318-22, Honkomagome, Bunkyo-ku, Tokyo, 113-8677, Japan. E-mail: yuhonajima@ gmail.com dx.doi.org/10.7889/hct-16-031 (C) The Japan Society for Hematopoietic Cell Transplantation. 
MSCs have important characteristics that make them suitable for aGVHD treatment. ${ }^{13}$ First, they have low immunogenicity, because their expression levels of HLA class I and II are low, and they lack expression of co-stimulatory molecules. ${ }^{14,15}$ Results of in vitro studies revealed that MSCs suppress allo-reactive T cells, allowing therapeutic use of MSCs from a third-party donor. Second, they have immunomodulatory effects. In pro-inflammatory conditions, they induce M2 macrophages to reduce inflammation. ${ }^{13}$ They promote regulatory $\mathrm{T}$ cells and suppress helper $\mathrm{T}$ cells including the Th1, Th2, and Th17 lineages. Third, through the same mechanism as leukocytes, MSCs can migrate into inflammatory sites, and thus, they do not induce systemic immunosuppression. ${ }^{16}$ Another advantage of administration of MSCs early after HSCT is their ability to produce interleukin-6, interleukin-8, and granulocyte-macrophage colony-stimulating factor, which may recruit and activate neutrophils to enhance the antimicrobial effect and promote the local protective immune system. ${ }^{14,15}$ These properties of MSCs are advantageous for aGVHD treatment.

\section{Clinical trials using MSCs as salvage treatment for SR-aGVHD}

Following the results from basic research, MSCs have been applied in the clinical setting. In 2004, Le Blanc et al. published the first case report of a 9-year-old boy with gradeIV aGVHD, which resolved dramatically after the infusion of MSCs from bone marrow (BM-MSCs). ${ }^{17}$ Following this promising result, they conducted a phase II study. ${ }^{18}$ Fifty-five patients were enrolled, $90 \%$ of whom had grade III-IV aGVHD, and the overall response (OR) rate and complete response (CR) rate were $71 \%$ and $55 \%$, respectively. Overall survival (OS) at 2 years was better (CR vs. less than CR: $52 \%$ vs. $13 \%, P=0.018)$, and transplant-related mortality was lower (CR vs. less than CR: $37 \%$ vs. $72 \%, P=0.002$ ). After this landmark report, many research groups conducted clinical trials evaluating the effect of MSCs for aGVHD.

However, controversial results were reported. Using Prochymal, which consists of BM-MSCs from a third-party donor, ${ }^{19-22}$ Osiris Therapeutics Inc. (Columbia, MD, USA) conducted a randomized double-blind study for treatment of SR-aGVHD（ClinicalTrial. gov NCT00366145), in which 76 transplantation centers in the US, Canada, Europe, and Australia participated. The primary endpoint was induction of a $\mathrm{CR}$ with a duration greater than or equal to 28 days. Although
Prochymal significantly improved the response of liver $(76 \%$ vs. $47 \%, P<0.05)$ and gut GVHD ( $82 \%$ vs. $68 \%, P<0.05)$, the response of skin was not significantly different between Prochymal and placebo groups $(78 \%$ vs. $77 \%, P=0.9)$ and thus, they could not demonstrate a superiority of MSCs over placebo in terms of the primary endpoint. ${ }^{23}$

\section{Clinical trials conducted in Japan}

In Japan, using an aliquot of BM from healthy volunteers, JR-031 was developed by JCR based on a license from Osiris. The manufacturing process of JR-031 is basically the same as Prochymal. Using JR-031, a phase I / II study was conducted in Japan. ${ }^{7}$ Fourteen patients with grade II - III SR-GVHD were enrolled. Of the 14 patients enrolled, 12 donors were unrelated, and eight patients received grafts from an HLA-mismatched donor. GVHD prophylaxis regimens basically consisted of a calcineurin inhibitor and a short course of MTX. Nine had grade II aGVHD, five had grade III aGVHD, and none had gradeIV aGVHD. As initial therapy, patients received $2.0 \times 10^{6} \mathrm{MSCs} / \mathrm{kg}$ twice a week for 4 weeks. The same dose of MSCs was administered weekly for 4 weeks as additional infusions (up to 12 infusions per patient). The unique parameters compared to other clinical trials were 1) no other second-line treatment was permitted, and 2) MSCs were given within $48 \mathrm{~h}$ of diagnosis of SR-aGVHD. Patients were observed for 24 weeks, and additional survival follow-up was done at 24 months. MSCs were first infused at a median of 47 days after HSCT. More than $90 \%$ of patients achieved a partial response or CR. The cumulative proportion achieving a CR by 24 weeks was also $92.9 \%$. The estimated time to reach $50 \%$ CR was 3 weeks (Figure 1A). All but one patient maintained the CR for more than 8 weeks, suggesting that these responses were highly durable. Regarding adverse events, no infusion reaction in the early phase or ectopic tissue formation in the late phase was observed. Thus, no MSCs therapy-associated events occurred. OS at 2 years after transplant was $57.1 \%$ (Figure 1B). No significant difference in OS was reported between patients with grade II and grade III aGVHD. The results of this study indicate that administration of third party-derived BM-MSCs was safe and effective. However, the efficacy of this therapy for grade III - IV could not be fully assessed.

A phase II / III study was conducted of patients with grade III and IV aGVHD. ${ }^{8}$ The treatment protocol was basically the same as described above, and the observation time was pro- 
Figure 1. Results of a phase I / II study using A TEMCELL in Japan. (A) Cumulative proportion of CR. (B) OS in all patients. Reproduced from Ref. 7.
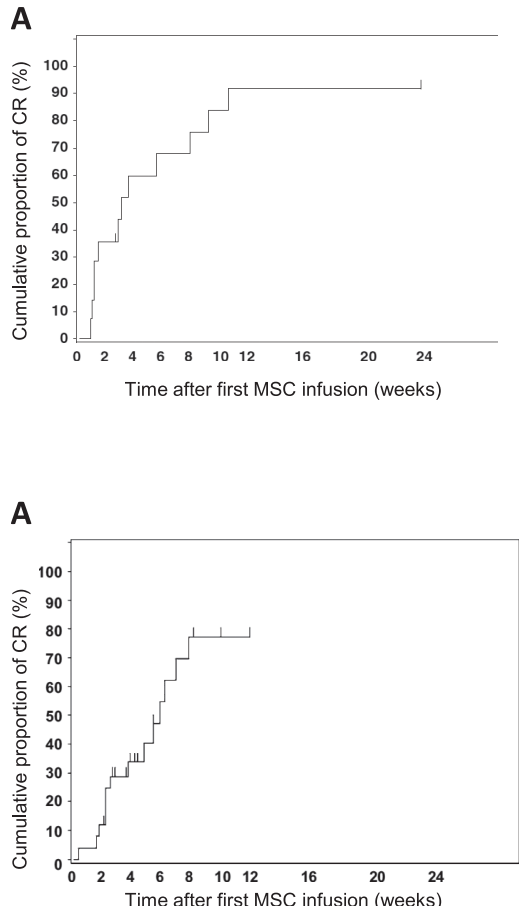

Figure 2. Results of a phase II / III study using TEMCELL in Japan. (A) Cumulative proportion of CR. (B) OS in all patients. (C) OS in patients who achieved OR (dotted line) was significantly better than that of patients who did not achieve OR (dashed line, $P<0.0001$ ). Reproduced from Ref. 8.

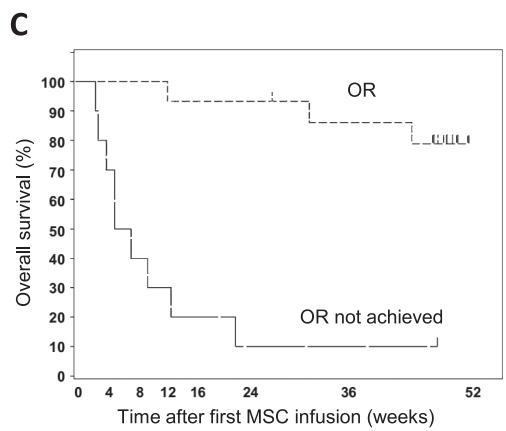

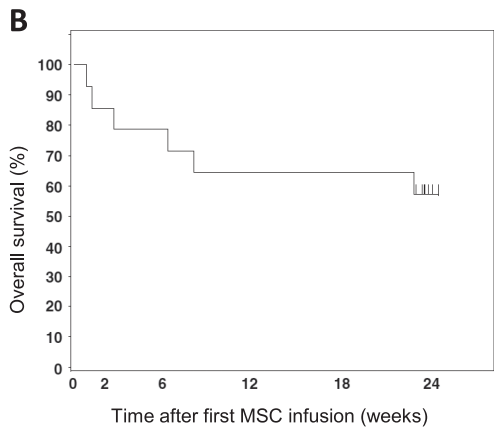

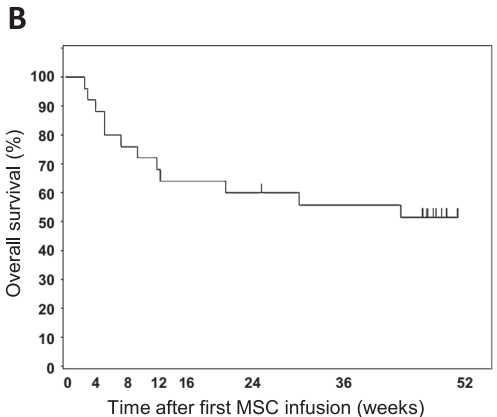

longed to 52 weeks. A total of 25 patients were enrolled, including 3 patients with grade IV aGVHD. The median time from HSCT to the first MSCs infusion was 45 days. The primary endpoint of this study, which was durable CR over 28 days, was reached in $48 \%$ of patients. Six patients maintained a CR with MSCs alone, whereas 11 out of 25 patients received additional immunosuppressive agents including ATG, MMF, MTX, etc. The OR by 4 weeks was $60 \%$, and the $\mathrm{CR}$ rate increased from 4 weeks to 24 weeks. The estimated time to reach $50 \% \mathrm{CR}$ was 6 weeks (Figure 2A). At 52 weeks, 12 patients $(48 \%)$ were alive with a CR (Figure $2 B$ ). The survival of patients showing an OR was significantly better than that of patients without an OR (Figure 2C). The steroid dose was reduced by two-thirds at 4 weeks and by half at 8 weeks.

Many prospective studies using MSCs for SR-aGVHD have been conducted (Table 1)..$^{7,8,18,20-22,24-34}$ As shown, the patients who were enrolled and the defined endpoints varied.
The heterogeneity of the treatment response criteria blurs the conclusion about the effectiveness of MSCs for aGVHD. ${ }^{35}$ In a recently published meta-analysis evaluating 336 patients in 13 studies, CR and OR for SR-aGVHD at 6 months were $28 \%$ and $72 \%$, respectively. ${ }^{36}$ With survival analysis, $63 \%$ of patients were alive at 6 months. These results also indicate the efficacy of MSCs therapy for SR-aGVHD. Further prospective studies are warranted to truly evaluate the details of the efficacy of this novel cellular therapy. In 30-40\% of patients who eventually achieved a $\mathrm{CR}$, maximum responses were observed 4-8 weeks after MSCs administration.

\section{The first approved cell drug, TEMCELL}

Following these favorable clinical results, JR-031, named TEMCELL ${ }^{\circledR}$ HS, was approved by the Japanese government as one of the first Cellular and Tissue-based Products in September 2015 and was listed in the national health insurance 
Table 1. Prospective trials of BM-MSCs for aGVHD

\begin{tabular}{|c|c|c|c|c|c|c|c|c|}
\hline Year & Author & $\mathrm{n}$ & $\begin{array}{l}\text { Grade } \\
\text { (n) }\end{array}$ & $\begin{array}{c}\text { Dose } \\
\text { (range) } \\
{\left[\times 10^{6}\right.} \\
\text { cells } / \mathrm{kg}]\end{array}$ & $\begin{array}{l}\text { Days from } \\
\text { aGVHD } \\
\text { diagnosis } \\
\text { to } 1 \mathrm{st} \\
\text { MSC } \\
\text { infusion } \\
\end{array}$ & Response & Overall survival & $\begin{array}{l}\text { Adult or } \\
\text { pediatric }\end{array}$ \\
\hline 2008 & Le Blanc $^{18}$ & 55 & $\begin{array}{l}\text { II: } 5, \\
\text { III: } 25, \\
\text { IV: } 25\end{array}$ & $\begin{array}{l}1.4 \\
(0.4-9.0)\end{array}$ & 27 & $\begin{array}{l}\text { CR } 55 \% \text {, } \\
\text { OR } 71 \%\end{array}$ & $\begin{array}{l}\text { N. A. [CR } 52 \% \text { vs. PR/NR } \\
16 \% \text { at } 2 \text { years] }\end{array}$ & $\begin{array}{l}\text { Adult (25 } \\
\text { pediatric) }\end{array}$ \\
\hline 2009 & Kebriaeri ${ }^{20 *}$ & 31 & $\begin{array}{l}\text { II : } 21, \\
\text { III: } 7, \\
\text { IV: } 3\end{array}$ & 2.0 or 8.0 & N. A. & $\begin{array}{l}\text { CR } 77 \% \text {, } \\
\text { OR } 93 \%\end{array}$ & $\begin{array}{l}71 \% \text { at day } 90 \text { [CR } 88 \% \text { vs. } \\
\text { PR/NR } 14 \%]\end{array}$ & Adult \\
\hline 2009 & von Bonin ${ }^{24}$ & 13 & $\begin{array}{l}\text { III: } 2 \\
\text { IV: } 9\end{array}$ & $\begin{array}{l}0.9 \\
(0.6-1.1)\end{array}$ & 16 & $\begin{array}{l}\text { CR } 15 \% \text {, } \\
\text { OR } 54 \%\end{array}$ & $\begin{array}{l}31 \% \text { after median } \mathrm{f} / \mathrm{u} \text { of } 8 \\
\text { months }\end{array}$ & Adult \\
\hline 2011 & Prasad $^{22 *}$ & 12 & $\begin{array}{l}\text { III: } 5 \\
\text { IV: } 7\end{array}$ & 2.0 or 8.0 & 46 & $\begin{array}{l}\text { CR } 58 \% \text {, } \\
\text { OR } 75 \%\end{array}$ & $\begin{array}{l}40 \% \text { at } 2 \text { years [CR } 68 \% \\
\text { vs. PR/NR 0\%] }\end{array}$ & Pediatric \\
\hline 2011 & Pérez-Simon ${ }^{25}$ & 10 & $\begin{array}{l}\text { III }: 5 \\
\text { IV: } 5\end{array}$ & $\begin{array}{l}2.0 \\
(1.0-2.0)\end{array}$ & 26 & $\begin{array}{l}\text { CR } 10 \% \text {, } \\
\text { OR } 70 \%\end{array}$ & $20 \%$ at 11 months & Adult \\
\hline 2012 & Herrmann ${ }^{26}$ & 12 & $\begin{array}{l}\text { II : } 1, \\
\text { III: } 7, \\
\text { IV: } 4\end{array}$ & $\begin{array}{l}2.0 \\
(1.7-2.3)\end{array}$ & N. A. & $\begin{array}{l}\text { CR } 58 \% \text {, } \\
\text { OR } 92 \%\end{array}$ & $55 \%$ at 30 months & Adult \\
\hline 2013 & Muroi $^{7 *}$ & 14 & $\begin{array}{l}\text { II : } 9 \\
\text { III: } 5\end{array}$ & 2.0 & $2^{4}$ & $\begin{array}{l}\text { CR } 50 \% \text {, } \\
\text { OR } 93 \%\end{array}$ & $57.1 \%$ at 96 weeks & $\begin{array}{l}\text { Adult ( } 1 \\
\text { pediatric) }\end{array}$ \\
\hline 2013 & Resnick $^{27}$ & 50 & $\begin{array}{l}\text { II - II : 8, } \\
\text { IV: } 42\end{array}$ & $\begin{array}{l}1.1 \\
(0.3-2.3)\end{array}$ & 27 & $\begin{array}{l}\text { CR } 34 \% \text {, } \\
\text { OR } 66 \%\end{array}$ & $56.3 \%$ at 3.6 years [DFS] & $\begin{array}{l}\text { Adult (25 } \\
\text { pediatric) }\end{array}$ \\
\hline 2013 & Ball|28 & 37 & III-IV: 37 & $\begin{array}{l}2.0 \\
(1.0-3.0)\end{array}$ & 13 & $\begin{array}{l}\text { CR } 65 \% \text {, } \\
\text { OR } 86 \%\end{array}$ & $\begin{array}{l}37 \% \text { at } 2.9 \text { years }[\mathrm{CR} 65 \% \\
\text { vs. PR/NR } 0 \% \text { ] }\end{array}$ & Pediatric \\
\hline 2014 & Introna ${ }^{29}$ & 31 & $\begin{array}{l}\text { II: } 11, \\
\text { III: } 17, \\
\text { IV: } 3\end{array}$ & $\begin{array}{l}1.5 \\
(0.8-3.1)\end{array}$ & 24 & $\begin{array}{l}\text { CR } 29 \% \text {, } \\
\text { OR } 74 \%\end{array}$ & $\begin{array}{l}50.0 \% \text { at } 1 \text { year, } 38.6 \% \text { at } \\
2 \text { years }\end{array}$ & Pediatric \\
\hline 2014 & Kurtzberg ${ }^{21 *}$ & 75 & $\begin{array}{l}\text { B: } 9, \\
\text { C: } 21 \\
\text { D: } 45^{\dagger}\end{array}$ & 2.0 & 30 & $\begin{array}{l}\text { CR N. A., } \\
\text { OR } 61 \%\end{array}$ & $\begin{array}{l}57.3 \% \text { at } 100 \text { days [OR } \\
76.1 \% \text { vs. NR } 27.6 \% \text { ] }\end{array}$ & Pediatric \\
\hline 2014 & Sanchez-Guijo ${ }^{30}$ & 24 & $\begin{array}{c}\text { II: } 7, \\
\text { III: } 15, \\
\text { IV: } 3\end{array}$ & $\begin{array}{l}1.1 \\
(0.7-1.3)\end{array}$ & N. A. & $\begin{array}{l}\text { CR } 46 \% \text {, } \\
\text { OR } 71 \%\end{array}$ & $\begin{array}{l}\text { N. A. [CR } 72.7 \% \text { vs. PR/ } \\
\text { NR } 21.4 \% \text { at } 1 \text { year] }\end{array}$ & Adult \\
\hline 2015 & Zhao ${ }^{31}$ & 28 & $\begin{array}{l}\text { II: } 4, \\
\text { III: } \\
\text { IV: } 16\end{array}$ & 1.0 & 17 & $\begin{array}{l}\text { CR } 61 \% \text {, } \\
\text { OR } 75 \%\end{array}$ & $\begin{array}{l}\text { N. A. [MSC } 46.4 \% \text { vs. Ctrl } \\
26.3 \% \text { at } 3 \text { years] }\end{array}$ & Adult \\
\hline 2016 & Muroi ${ }^{8 *}$ & 25 & $\begin{array}{l}\text { III: } 22, \\
\text { IV: } 3\end{array}$ & 2.0 & $2^{4}$ & $\begin{array}{l}\text { CR } 24 \% \text {, } \\
\text { OR } 60 \%\end{array}$ & $48 \%$ at 52 weeks & Adult \\
\hline 2016 & von Dalowski ${ }^{32}$ & 58 & $\begin{array}{l}\text { III: } 9 \\
\text { IV: } 49\end{array}$ & 1.0 & 12 & $\begin{array}{l}\text { C R } 9 \% \text {, } \\
\text { OR } 47 \%\end{array}$ & $19 \%$ at 1 year & Adult \\
\hline 2016 & Erbey $^{33}$ & 33 & $\begin{array}{l}\text { III: } 26 \\
\text { IV: } 28\end{array}$ & $\begin{array}{l}1.2 \\
(0.5-2.8)\end{array}$ & 18 & $\begin{array}{l}\text { CR } 55 \% \text {, } \\
\text { OR } 76 \%\end{array}$ & $\begin{array}{l}\text { N. A. [CR } 63.8 \% \text { vs. PR/ } \\
\text { NR } 29.4 \% \text { at } 1 \text { year] }\end{array}$ & Pediatric \\
\hline
\end{tabular}

Abbreviations: $\mathrm{BM}$, bone marrow; $\mathrm{CR}$, complete response; $\mathrm{OR}$, overall response; PR, partial response; NR, no response; aGVHD, acute graft-versus-host-disease; MSC, mesenchymal stem cell; N. A., not available. *Studies using Prochymal or the same protocol for preparing MSCs. "Interval between diagnosis of steroid-refractory aGVHD and MSC infusion. ${ }^{\dagger}$ aGVHD grades using the Center for International Blood and Marrow Transplant Registry grading scheme. ${ }^{34}$

reimbursement in November 2015. The price of TEMCELL was set at $¥ 868,680$ per bag of $7.2 \times 10^{7}$ cells in $10.8 \mathrm{ml}$ (Figure $3 \mathbf{A}$ ). Two bags are required for the average adult with a body weight over $36 \mathrm{~kg}$. The bags must be transferred in ultra- cold conditions $\left(-150^{\circ} \mathrm{C}\right)$ using a specialty drug distribution unit (Figure 3B). One treatment course of TEMCELL in an adult patient will cost $¥ 13,898,880$ (approximately US\$130,000) or up to $¥ 20,848,320$ (approximately 
Figure 3. Pictures of TEMCELL (A) and the specialty drug distribution unit $(B)$
A

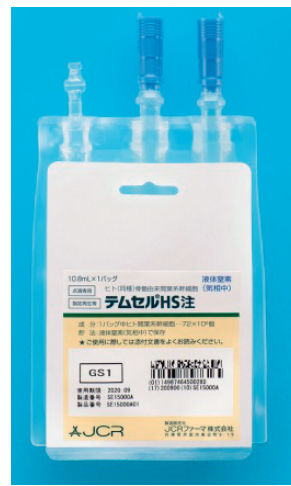

B

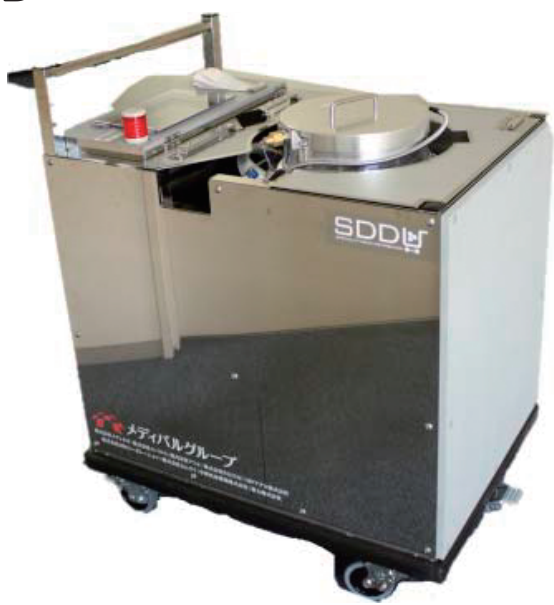

Table 2. Potential concerns with MSC therapy in comparison to other treatments

\begin{tabular}{|c|c|c|c|}
\hline & MSCs & rATG & MMF \\
\hline Mechanism & $\begin{array}{c}\text { Inhibition of Th lineage } \\
\text { Promotion of Tregs and M2 macrophages } \\
\text { (By direct cell contact) }\end{array}$ & Depletion of $\mathrm{T}, \mathrm{B}$, and NK cells & $\begin{array}{c}\text { Inhibition of DNA and RNA synthesis } \\
\text { in Th lineage cells }\end{array}$ \\
\hline Immunosuppression & $\begin{array}{c}\text { Local } \\
\text { Mild } \\
\text { (Anti-microbial?) }\end{array}$ & $\begin{array}{l}\text { Systemic } \\
\text { Severe }\end{array}$ & $\begin{array}{l}\text { Systemic } \\
\text { Moderate }\end{array}$ \\
\hline Adverse effect & $\begin{array}{l}\text { Ectopic tissue formation? } \\
\text { Transformation? } \\
\text { Pneumonia (pulmonary infection)? }\end{array}$ & $\begin{array}{l}\text { Viral infection } \\
\text { Allergic reaction } \\
\text { Cytopenia }\end{array}$ & $\begin{array}{l}\text { Diarrhea } \\
\text { Cytopenia }\end{array}$ \\
\hline $\begin{array}{l}\text { Cost } \\
\text { (BW } 50 \mathrm{~kg} \text { ) }\end{array}$ & $\begin{array}{c}\text { Extremely high } \\
¥ 868,680 / \text { bag } \\
2 \text { bags } / \text { day, twice a week } \times 4 \\
¥ 13,898,880\end{array}$ & $\begin{array}{c}\text { Moderate to High } \\
¥ 40,545 / 25 \text {-mg vial } \\
1-5 \mathrm{mg} / \mathrm{kg} \\
¥ 81,090-¥ 405,540\end{array}$ & $\begin{array}{c}\text { Moderate } \\
¥ 293.3 / 250 \text {-mg tab } \\
20 \mathrm{mg} / \mathrm{kg} \text { twice daily } \\
¥ 70,392 / \text { month }\end{array}$ \\
\hline Other considerations & $\begin{array}{l}\text { Various sources } \\
\text { (Umbilical cord, adipose tissue, and PB) }\end{array}$ & Prolonged immunosuppression & $\begin{array}{c}\text { Oral medicine only in Japan } \\
\text { Variation in blood concentration }\end{array}$ \\
\hline
\end{tabular}

Abbreviations: MSC, mesenchymal stem cell; rATG, recombinant anti-thymocyte globulin; MMF, mycophenolate mofetil; Th, helper T cell; Tregs, regulatory T cells; NK, natural killer cell; BW, body weight; aGVHD, acute graft-versus-host-disease; PB, peripheral blood.

US\$200,000). The product was launched on February 24, 2016 with temporary usage restriction in several institutions that participated in the clinical trials. For post-marketing drug surveillance, all patients who received TEMCELL have been registered to allow analysis of their outcomes for evaluation of the efficacy and adverse events.

\section{Issues of concern}

Although MSC therapy is a promising treatment, several concerns have been identified (Table 2). First are the safety issues associated with the stem cell properties of MSCs. Use of these cells involves the possibility of ectopic tissue formation or malignant transformation following many passages, which was suggested by in vivo and in vitro pre-clinical stud- ies using murine MSCs. ${ }^{37}$ However, this susceptibility to malignant transformation of human MSCs has not been directly confirmed. ${ }^{13}$ Furthermore, recent studies indicated that allogeneic donor MSCs may not completely be immuneprivileged and infused MSCs may eventually be rejected by the recipient. ${ }^{38}$ Past histological studies of specimens from autopsies and biopsies of patients with SR-aGVHD who received MSCs revealed no evidence confirming these safety concerns, ${ }^{39}$ although further long-term observation may be required. Second, the cost of this treatment is surprising at over $¥ 800,000$ per bag, requiring $¥ 14,000,000$ per entire course. Third, due to their immunosuppressive effect, MSCs may increase the risk of opportunistic infection in highly immune-deficient recipients. ${ }^{40}$ The prospective registration of all patients will help address these issues. 
Compared with other agents available in Japan, MSCs treatment carries distinct properties. Currently, $\mathrm{MMF}^{4,41-44}$ and ATG $^{3,45-47}$ are the two most frequently used second-line treatments for SR-aGVHD. ${ }^{48}$ In Japan, rabbit ATG was approved in 2008 for SR-aGVHD. However, its long-term efficacy is yet to be confirmed. In terms of the mechanism, MSCs migrate into locally inflamed sites and inhibit helper $\mathrm{T}$ cells or promote regulatory $\mathrm{T}$ cells, mainly via direct cell contact. Thus, adverse events derived from severe immunosuppressive effects may be reduced compared to other agents. The cost for MSCs is substantial (Table 2), and criteria to select patients who will benefit from this treatment will be crucial. Another consideration is various sources of MSCs for clinical use. Although most MSCs used for aGVHD treatment were derived from BM in previous reports, other tissues including adipose tissues, ${ }^{49}$ umbilical cord blood $(\mathrm{CB}),{ }^{50,51}$ and placenta $^{52,53}$ are potential sources of MSCs and have different properties compared to BM-derived MSCs. Fang et al. reported promising results of a clinical study using adipose tissue-derived MSCs in which 5 out of 6 patients with grade III -IV SR-aGVHD achieved a CR. ${ }^{49}$ Nagamura et al. have revealed that Wharton's Jelly-derived MSCs do not express HLA-DR, even in the presence of the pro-inflammatory cytokine, interferon-gamma. ${ }^{50,51} \mathrm{~A}$ phase I study using CBderived MSCs for SR-aGVHD is currently under preparation in Japan. These differences in MSC sources may affect the efficacy and should be evaluated in the near future.

\section{Conclusion}

MSCs have unique characteristics that are advantageous for aGVHD treatment. Results of clinical studies in Japan were favorable enough to achieve insurance approval. However, no data are available that compare the use of MSCs with other options. Thus, now that this treatment is publicly available, registration of all cases for post-marketing study is likely to produce pivotal data.

\section{Acknowledgement}

This work was supported in part by Japan Leukemia Research Fund.

\section{Conflict of interest disclosure}

The authors have no conflicts of interest to report.

\section{References}

1. Gooley TA, Chien JW, Pergam SA, et al. Reduced mortality after allogeneic hematopoietic-cell transplantation. N Engl J Med. 2010; 363: 2091-2101.

2. Murata M, Nakasone H, Kanda J, et al. Clinical factors predicting the response of acute graft-versus-host disease to corticosteroid therapy: an analysis from the GVHD Working Group of the Japan Society for Hematopoietic Cell Transplantation. Biol Blood Marrow Transplant. 2013; 19: 1183-1189.

3. Ohashi K, Tanaka Y, Mori S, et al. Low-dose antithymocyte globulin for treatment of steroid-pulse-resistant acute graftversus-host disease. Int J Hematol. 2003; 77: 99-102.

4. Furlong T, Martin P, Flowers ME, et al. Therapy with mycophenolate mofetil for refractory acute and chronic GVHD. Bone Marrow Transplant. 2009; 44: 739-748.

5. Inagaki J, Fukano R, Kodama Y, Nishimura M, Shimokawa M, Okamura J. Safety and efficacy of low-dose methotrexate for pediatric patients with steroid-refractory acute graft-versushost disease after hematopoietic stem cell transplantation. Ann Hematol. 2014; 93: 645-651.

6. Couriel D, Saliba R, Hicks K, et al. Tumor necrosis factor-alpha blockade for the treatment of acute GVHD. Blood. 2004; 104: 649-654.

7. Muroi K, Miyamura K, Ohashi K, et al. Unrelated allogeneic bone marrow-derived mesenchymal stem cells for steroidrefractory acute graft-versus-host disease: a phase I / II study. Int J Hematol. 2013; 98: 206-213.

8. Muroi K, Miyamura K, Okada M, et al. Bone marrow-derived mesenchymal stem cells (JR-031) for steroid-refractory grade III or IV acute graft-versus-host disease: a phase II / III study. Int J Hematol. 2016; 103: 243-250.

9. Miyamura K. Insurance approval of mesenchymal stem cell for acute GVHD in Japan: need of follow up for some remaining concerns. Int J Hematol. 2016; 103: 155-164.

10. Miura Y. Human bone marrow mesenchymal stromal/stem cells: current clinical applications and potential for hematology. Int J Hematol. 2016; 103: 122-128.

11. Horwitz EM, Le Blanc K, Dominici M, et al. Clarification of the nomenclature for MSC: The International Society for Cellular Therapy position statement. Cytotherapy. 2005; 7: 393395.

12. Salem HK, Thiemermann C. Mesenchymal stromal cells: current understanding and clinical status. Stem Cells. 2010; 28: 585-596.

13. Bernardo ME, Fibbe WE. Mesenchymal stromal cells: sensors and switchers of inflammation. Cell Stem Cell. 2013; 13: 392402.

14. English K. Mechanisms of mesenchymal stromal cell immunomodulation. Immunol Cell Biol. 2013; 91: 19-26.

15. Le Blanc K, Mougiakakos D. Multipotent mesenchymal stromal cells and the innate immune system. Nat Rev Immunol. 2012; 12: 383-396.

16. Fox JM, Chamberlain G, Ashton BA, Middleton J. Recent 
advances into the understanding of mesenchymal stem cell trafficking. Br J Haematol. 2007; 137: 491-502.

17. Le Blanc K, Rasmusson I, Sundberg B, et al. Treatment of severe acute graft-versus-host disease with third party haploidentical mesenchymal stem cells. Lancet. 2004; 363: 14391441.

18. Le Blanc K, Frassoni F, Ball L, et al. Mesenchymal stem cells for treatment of steroid-resistant, severe, acute graft-versushost disease: a phase II study. Lancet. 2008; 371: 1579-1586.

19. Daly A. Remestemcel-L, the first cellular therapy product for the treatment of graft-versus-host disease. Drugs Today (Barc). 2012; 48: 773-783.

20. Kebriaei P, Isola L, Bahceci E, et al. Adult human mesenchymal stem cells added to corticosteroid therapy for the treatment of acute graft-versus-host disease. Biol Blood Marrow Transplant. 2009; 15: 804-811.

21. Kurtzberg J, Prockop S, Teira P, et al. Allogeneic human mesenchymal stem cell therapy (remestemcel-L, Prochymal) as a rescue agent for severe refractory acute graft-versus-host disease in pediatric patients. Biol Blood Marrow Transplant. 2014; 20: 229-235.

22. Prasad VK, Lucas KG, Kleiner GI, et al. Efficacy and safety of ex vivo cultured adult human mesenchymal stem cells (Prochymal) in pediatric patients with severe refractory acute graftversus-host disease in a compassionate use study. Biol Blood Marrow Transplant. 2011; 17: 534-541.

23. Martin PJ, Uberti JP, Soiffer RJ, et al. Prochymal Improves Response Rates In Patients With Steroid-Refractory Acute Graft Versus Host Disease (SR-GVHD) Involving The Liver And Gut: Results Of A Randomized, Placebo-Controlled, Multicenter Phase III Trial In GVHD. Biol Blood Marrow Transplant; 16: S169-S170.

24. von Bonin M, Stolzel F, Goedecke A, et al. Treatment of refractory acute GVHD with third-party MSC expanded in platelet lysate-containing medium. Bone Marrow Transplant. 2009; 43: $245-251$.

25. Perez-Simon JA, Lopez-Villar O, Andreu EJ, et al. Mesenchymal stem cells expanded in vitro with human serum for the treatment of acute and chronic graft-versus-host disease: results of a phase I / II clinical trial. Haematologica. 2011; 96: 1072-1076.

26. Herrmann R, Sturm M, Shaw K, et al. Mesenchymal stromal cell therapy for steroid-refractory acute and chronic graft versus host disease: a phase 1 study. Int J Hematol. 2012; 95: 182-188.

27. Resnick IB, Barkats C, Shapira MY, et al. Treatment of severe steroid resistant acute GVHD with mesenchymal stromal cells (MSC). Am J Blood Res. 2013; 3: 225-238.

28. Ball LM, Bernardo ME, Roelofs $\mathrm{H}$, et al. Multiple infusions of mesenchymal stromal cells induce sustained remission in children with steroid-refractory, grade III - IV acute graft-versushost disease. Br J Haematol. 2013; 163: 501-509.

29. Introna M, Lucchini G, Dander E, et al. Treatment of graft ver- sus host disease with mesenchymal stromal cells: a phase I study on 40 adult and pediatric patients. Biol Blood Marrow Transplant. 2014; 20: 375-381.

30. Sanchez-Guijo F, Caballero-Velazquez T, Lopez-Villar O, et al. Sequential third-party mesenchymal stromal cell therapy for refractory acute graft-versus-host disease. Biol Blood Marrow Transplant. 2014; 20: 1580-1585.

31. Zhao K, Lou R, Huang F, et al. Immunomodulation effects of mesenchymal stromal cells on acute graft-versus-host disease after hematopoietic stem cell transplantation. Biol Blood Marrow Transplant. 2015; 21: 97-104.

32. von Dalowski F, Kramer M, Wermke M, et al. Mesenchymal Stromal Cells for Treatment of Acute Steroid-Refractory Graft Versus Host Disease: Clinical Responses and Long-Term Outcome. Stem Cells. 2016; 34: 357-366.

33. Erbey F, Atay D, Akcay A, Ovali E, Ozturk G. Mesenchymal Stem Cell Treatment for Steroid Refractory Graft-versus-Host Disease in Children: A Pilot and First Study from Turkey. Stem Cells Int. 2016; 2016: 1641402.

34. Rowlings PA, Przepiorka D, Klein JP, et al. IBMTR Severity Index for grading acute graft-versus-host disease: retrospective comparison with Glucksberg grade. Br J Haematol. 1997; 97: 855-864.

35. Rizk M, Monaghan M, Shorr R, et al. Heterogeneity in Studies of Mesenchymal Stromal Cells to Treat or Prevent Graft-versus-Host Disease: A Scoping Review of the Evidence. Biol Blood Marrow Transplant. 2016; 22: 1416-1423.

36. Hashmi S, Ahmed M, Murad MH, et al. Survival after mesenchymal stromal cell therapy in steroid-refractory acute graftversus-host disease: systematic review and meta-analysis. Lancet Haematol. 2016; 3: e45-52.

37. Casiraghi F, Remuzzi G, Abbate M, Perico N. Multipotent mesenchymal stromal cell therapy and risk of malignancies. Stem Cell Rev. 2013; 9: 65-79.

38. Ankrum JA, Ong JF, Karp JM. Mesenchymal stem cells: immune evasive, not immune privileged. Nat Biotechnol. 2014; 32: 252-260.

39. von Bahr L, Batsis I, Moll G, et al. Analysis of tissues following mesenchymal stromal cell therapy in humans indicates limited long-term engraftment and no ectopic tissue formation. Stem Cells. 2012; 30: 1575-1578.

40. Remberger M, Ringden O. Treatment of severe acute graftversus-host disease with mesenchymal stromal cells: a comparison with non-MSC treated patients. Int J Hematol. 2012; 96: $822-824$.

41. Alousi AM, Weisdorf DJ, Logan BR, et al. Etanercept, mycophenolate, denileukin, or pentostatin plus corticosteroids for acute graft-versus-host disease: a randomized phase 2 trial from the Blood and Marrow Transplant Clinical Trials Network. Blood. 2009; 114: 511-517.

42. Iida M, Fukuda T, Ikegame K, et al. Use of mycophenolate mofetil in patients received allogeneic hematopoietic stem cell transplantation in Japan. Int J Hematol. 2011; 93: 523-531. 
43. Onishi C, Ohashi K, Sawada T, et al. A high risk of life-threatening infectious complications in mycophenolate mofetil treatment for acute or chronic graft-versus-host disease. Int J Hematol. 2010; 91: 464-470.

44. Takami A, Mochizuki K, Okumura H, et al. Mycophenolate mofetil is effective and well tolerated in the treatment of refractory acute and chronic graft-versus-host disease. Int J Hematol. 2006; 83: 80-85.

45. Van Lint MT, Milone G, Leotta S, et al. Treatment of acute graft-versus-host disease with prednisolone: significant survival advantage for day +5 responders and no advantage for nonresponders receiving anti-thymocyte globulin. Blood. 2006; 107: 4177-4181.

46. Dugan MJ, DeFor TE, Steinbuch M, Filipovich AH, Weisdorf DJ. ATG plus corticosteroid therapy for acute graft-versus-host disease: predictors of response and survival. Ann Hematol. 1997; 75: 41-46.

47. Nishimoto M, Nakamae H, Koh H, et al. Response-guided therapy for steroid-refractory acute GVHD starting with verylow-dose antithymocyte globulin. Exp Hematol. 2015; 43: 177-179.
48. Lee SJ, Joffe S, Artz AS, et al. Individual physician practice variation in hematopoietic cell transplantation. J Clin Oncol. 2008; 26: 2162-2170.

49. Fang B, Song Y, Liao L, Zhang Y, Zhao RC. Favorable response to human adipose tissue-derived mesenchymal stem cells in steroid-refractory acute graft-versus-host disease. Transplant Proc. 2007; 39: 3358-3362.

50. He H, Nagamura-Inoue T, Takahashi A, et al. Immunosuppressive properties of Wharton's jelly-derived mesenchymal stromal cells in vitro. Int J Hematol. 2015; 102: 368-378.

51. Nagamura-Inoue T, He H. Umbilical cord-derived mesenchymal stem cells: Their advantages and potential clinical utility. World J Stem Cells. 2014; 6: 195-202.

52. Li C, Zhang W, Jiang X, Mao N. Human-placenta-derived mesenchymal stem cells inhibit proliferation and function of allogeneic immune cells. Cell Tissue Res. 2007; 330: 437-446.

53. Jang MJ, Kim HS, Lee HG, et al. Placenta-derived mesenchymal stem cells have an immunomodulatory effect that can control acute graft-versus-host disease in mice. Acta Haematol. 2013; 129: 197-206. 